\title{
Den spirituelle vending - og den permanente undtagelsestilstand
}

\author{
Af Katrin Hjort *)
}

"[...] hvis børnene pjækker og ikke møder op i skolen, så trækkes i børnechecken, siger statsminister Lars Løkke Rasmussen [...]”

(Larsen, 2018)

\begin{abstract}
Resumé
Den italienske jurist og politiske filosof Georgio Agamben taler om undtagelsestilstanden, hvor den suveræne, der er garant for sikkerhed - lov og ret - sætter lov og ret ud af kraft af hensyn til statens sikkerhed. Agamben taler om voldsomme begivenheder i det 20. århundredes historie. Han beskriver de lejre, hvor ekskluderede er blevet isoleret, og han viser, hvordan den retsløshed, der først gjaldt for nogle i nogen tid, kan blive permanent for alle altid. De tendenser, Agamben beskriver, ligner påfaldende noget, vi ser i Danmark i dag i forbindelse med det såkaldte paradigmeskift i migrations- og asylpolitikken. Ligheden er specielt tydelig i forbindelse med ghettoplanen og hjemsendelsesydelsen, men også i forbindelse med lejren Sjælsmark og øen Lindholm. Som Ivan Krastev formulerer det, så erstattes den europæiske civilisations drøm om Utopia - frihed og demokrati - af drømmen om Nativia - det sted, hvor alle de forkerte og uønskede kan sendes hen. Denne dagdrøm - kan - som Ernst Bloch sagde - udnyttes politisk og polarisere samfundet, men også udgøre et håb, vi kan lære os at følge.
\end{abstract}

*) Katrin Hjort er dr.phil. og professor ved Syddansk Universitet. 


\section{A. Indledning}

Den affektive økonomi suppleres i dag af en ”Spirituel Økonomi”. ”Den Spirituelle Vending” kan forstås som søgen efter en mening, der transcenderer det mundæne - den jordiske væren nu og her - og repræsenterer et håb om et bedre liv (Arendt, [1958] 2005). Men i værste fald kan den spirituelle stræben også blive til nye former for økonomisk udbytning og politisk udnyttelse. Ligesom den i bedste fald kan rumme en drøm, som er værd at følge (Bloch, [1954] 1994).

Her præsenteres "The Spiritual Turn" eller "Den Spirituelle Vending”, som den bl.a. beskrives i Dick Houtman \& Stef Aupers' aktuelle undersøgelse af multi-religiøsitet i de vestlige lande (Houtman, 2007). De økonomiske dimensioner af den spirituelle vending begribes med Karl Marx' kategoriseringer af de formelle subsumptionsprocesser (Marx, 1857). De politiske dimensioner af spiritualiseringen, som jeg vil benævne den, ses i lyset af Georgio Agamben’s teorier om sikkerhedsregimet og den permanente undtagelsestilstand, hvis paradigme er "lejren" udelukkelsen og indespærringen (Agamben, [1995]2014; 2016). Der henvises i forlængelse heraf til Ivan Krastev's beskrivelse af, hvordan den europæiske civilisations drøm om et frit og demokratisk Utopia trues af Nativia - ønsket om øen, hvor alle de uønskede kan sendes hen (Krastev, 2017). Afslutningsvis citeres Ernst Bloch om håb (Bloch, ([1954] 1995).

Indledningsvis vil jeg understrege, at jeg i denne artikel ikke diskuterer spørgsmål om Guds eksistens. Ærindet er en samtidsdiagnose: Hvordan vi kan forstå samtidens omfattende optagethed af det åndelige, og hvilke samfundsmæssige konsekvenser kan spiritualiseringen få?

\section{B. Samtidsdiagnose}

\section{Den politiske eller populistiske spiritualitet.}

Da Michel Foucault i 1979 kom hjem fra sin rejse til Iran under opstanden mod Shahen i 1978, og skulle forklare eller legitimere sig i de vestlige medier, talte han om håb i forbindelse med politisk spiritualitet. Om (masse-)opstande, der ikke tematiseres i moderne vestlig forstand som spørgsmål om klassemodsætninger og demokrati, men som i stedet trækker på religiøse eller åndelige traditioner fra lokalområderne. Den politiske spiritualitet kobler en diffus og forskelligartet utilpashed og utilfredshed sammen til en kollektiv bevægelse, ønsket om en stærk leder og håbet om forbedring. For Irans vedkommende blev det til opgøret med Shahen og opbakningen bag ayatollah Khomeini (Raffnsøe, 2018). 
De hollandske forskere Dick Houtman og Stef Aupers var de første, der introducerede begrebet "The Spiritual Turn” eller "Den spirituelle vending” i en international forskningsoffentlighed. De taler ikke om politisk spiritualitet i Foucaults forstand, men snarere om, hvad man kunne betegne som populistisk spiritualitet. Houtman og Aupers hovedpointe er, at vi i de sen-moderne vestlige samfund, inklusive Danmark, ikke kun oplever de-traditionalisering og opløsning af etablerede trosfælleskaber, men også en stærk vækst i, hvad de betegner som en "Post-kristen Spiritualitet”, "Semi-religiøsitet”, ”Multi-religiøsitet” eller mere polemisk som "det religiøse supermarked" eller det "Selv-sakrale", helliggørelse af eget selv.i

Statistisk set kan undersøgelsens resultater forklares, skriver Houtman og Aupers, dels på baggrund af nationale forskelle og dels inter-generativt som resultat af udskiftning af kohorter af ældre med mere spirituelt orienterede yngre kohorter. Når det kommer til de nationale forskelle, så fører Irland, USA, Belgien og Holland med hensyn til stigning i Post-Christian spiritualitet. Italien og Island ligger i bunden. Danmark indtager en middelposition med en mindre stigning. Væksten er tilsyneladende størst i de nationer, der som udgangspunkt er blandede mht. religiøsitet, og den er stærkest blandt de højest uddannede og mest socialt velstillede. Men den er ikke forbeholdt en ung generation i et specielt segment, som da sangen "The Age of Aquarius" blev sunget i musicalen "Hair” på Broadway i ungdomsoprørets tidligste fase i 1968. ii

\section{Den femte reelle subsumption}

I min doktordisputats (Hjort, 2001, 2005, 2008, 2012, 2013) fremskrev jeg en analysemodel til begribelse af, hvad jeg betegner som de fire reelle subsumptioner. I denne artikel argumenterer jeg for, at vi i øjeblikket oplever en femte reel subsumption, hvor den åndelige eller spirituelle søgen bliver et nyt globalt forretningsgrundlag, ”Den spirituelle Økonomi”.

Udgangspunktet er Karl Marx’s definition i Grundridse af formel og reel subsumption (Marx 1957). Det vil sige hans analyse af, hvordan konkurrencen på markedet og den dermed faldende profitrate implicerer en akkumulationstvang, der nødvendiggør stadig nye eksplorationsområder. Stadig nye materielle og immaterielle "fænomener”, der på forskellig vis kan opfylde menneskers fysiske og symbolske behov, må gøres til "genstande”, som kan købes og sælges på måder, der kan generere profit. Processer, der benævnes som konsekvenserne af "kapitalens formsubsumptive interventionspotens” (Schanz, 1973). Herved formbestemmes materialiteternes egen-logikker på 
stadigt nye måder. Det formbare eksponeres - det uformelige ekskluderes, men kan senere igen inkluderes på de måder - og i det omfang - det bliver teknologisk muligt (Thomsen, 1975). Her melder den spirituelle eller åndelige søgen sig som et område, modernitetens instrumentelle rationalitet har ekskluderet - og dermed potentielt eksponeret - men som i dag kan antage nye former, der kan inddrages i de økonomiske valoriseringsprocesser.

Når man tegner et sådant billede, må der imidlertid også tages nogle forbehold. Det nye er ikke, at religion og penge knyttes sammen. Jævnfør en række af de store kirkesamfund. Det nye er, at troen i stigende omfang og på nye måder bliver områder, der kan investeres i med henblik på afkast. Figuren nedenfor er en analytisk konstruktion, jeg har lavet. Jeg vil understrege, at her ikke er tale om en fast historisk progression, men om processer, der kan foregå simultant såvel som ikke-simultant. Her er heller ikke tale om en hierarkisering. Felterne i figuren repræsenterer ikke former for arbejde, der har særlig værdi for den samfundsmæssige reproduktion. Eksempelvis kan det u-formaliserede arbejde som husarbejde og frivilligt arbejde være nødvendigt for den menneskelige overlevelse i mange forskellige kontekster, globalt og historisk.

\begin{tabular}{|c|c|c|c|c|}
\hline & & Genstand & Videnskab og teknologi & Lokalisering \\
\hline $\begin{array}{l}1 . \\
\text { Reelle } \\
\text { Subs. }\end{array}$ & $\begin{array}{l}\text { Industri } \\
\text { arbejde }\end{array}$ & Den døde natur & $\begin{array}{l}\text { Naturvidenskab: fysik og } \\
\text { kemi. } \\
\text { Stationær energi (damp, kul) }\end{array}$ & $\begin{array}{l}\text { Lokalt } \\
\text { Nationalt }\end{array}$ \\
\hline $\begin{array}{l}. \\
\text { Reelle } \\
\text { Subs. }\end{array}$ & $\begin{array}{l}\text { Landbrugs } \\
\text { arbejde }\end{array}$ & Den levende natur & $\begin{array}{l}\text { Naturvidenskab: biologi, } \\
\text { geologi } \\
\text { Mobil energi (benzin, el) } \\
\text { Genteknologi }\end{array}$ & $\begin{array}{l}\text { Nationalt } \\
\text { Internationalt }\end{array}$ \\
\hline $\begin{array}{l}3 . \\
\text { Reelle } \\
\text { Subs. }\end{array}$ & $\begin{array}{l}\text { Kognitivt } \\
\text { arbejde }\end{array}$ & $\begin{array}{l}\text { Menneskers intellekt } \\
\text { og symboler }\end{array}$ & $\begin{array}{l}\text { Systemteori og } \\
\text { computerscience } \\
\text { Informationsteknologi }\end{array}$ & Multinationalt \\
\hline $\begin{array}{l}4 . \\
\text { Reelle } \\
\text { Subs. }\end{array}$ & $\begin{array}{l}\text { Affektivt } \\
\text { arbejde }^{i v}\end{array}$ & $\begin{array}{l}\text { Menneskers sind og } \\
\text { kroppe }\end{array}$ & $\begin{array}{l}\text { Psy-sciences, Self- } \\
\text { technologies, Bio-sciences, } \\
\text { Bio-teknologier }\end{array}$ & $\begin{array}{l}\text { Lokalt } \\
\text { Transnationalt }\end{array}$ \\
\hline $\begin{array}{l}5 . \\
\text { Reelle } \\
\text { Subs. }\end{array}$ & $\begin{array}{l}\text { Spirituelt } \\
\text { arbejde }\end{array}$ & $\begin{array}{l}\text { Menneskers åndelige } \\
\text { eller religiøse søgen }\end{array}$ & $\begin{array}{l}\text { (Re-)vitalisering af etik, } \\
\text { mystik og metafysik. Ny } \\
\text { alkymi? }\end{array}$ & "Transglobalt" \\
\hline
\end{tabular}

Spørgsmålene bag figuren er: Hvad bliver udgrænset - fraværende og potentielt nærværende når det menneskelige arbejde bliver organiseret på bestemte måder? Hvad kan på et givet tidspunkt subsumeres reelt, dvs. kommodificeres, kommercialiseres og kapitaliseres (vare, penge, 
kapital) ved hjælp af den forhåndenværende videnskab og teknologi inden for en given lokalisering? Her kommer det spirituelle for alvor i spil.

\section{Den spirituelle økonomi}

Som udgangspunkt for dette afsnit skal det igen understreges, at jeg ikke beskæftiger mig med de subjektive betydninger af optagetheden og interessen for det spirituelle, men eksklusivt med de økonomiske aspekter. Men det betyder ikke, at den spirituelle bølge kan reduceres til økonomi. Selvom man ikke tror på en Gud, kan man godt have guddommelige oplevelser. Jeg vil ikke underkende virkningen af de spirituelle aktiviteter, der om ikke andet på rationalistisk vis kan forklares med placebo-effekten.

Mit ærinde her er imidlertid at henlede opmærksomheden dels på den økonomiske udbytning, spiritualiseringen kan implicere (salg af "varm luft" eller "buldren fra tomme tønder"), dels - som jeg vil gå nærmere ind på i næste afsnit - den politiske udnyttelse. Her følger jeg mistænksomhedens hermeneutik (Ranciere, [2005] 2013). Min alvorligste bekymring er, at den spirituelle bølge kan medvirke til at skabe eller naturliggøre en dikotomiserende diskurs (dem versus os), der kan bidrage til etableringen af den permanente undtagelsestilstand og lejrene under sikkerhedsregimet. Ikke kun globalt, nationalt og regionalt, men også lokalt i Danmark.

Hvis man undersøger den spirituelle økonomi nærmere, repræsenterer den en stadig mere omfattende forretning, der kan inkludere køb og salg af såvel materielle som immaterielle varer.

Med hensyn til det materielle kan det som et kuriosum nævnes, at dags dato, 23.11.2018, giver opslaget "Buddhaer og Engle” (på dansk) 342.000 hits på Google. Det siger selvfølgelig ikke, at disse genstande er blevet købt, men det fortæller, at der er mange, der ser et forretningsgrundlag i at sælge dem via nettet. Med hensyn til det immaterielle oplever vi et stadigt voksende salg af, hvad jeg vil benævne som spiritainment - events eller performances, der appellerer til sanserne via musik, lys, lyd, lugte, smag, berøring og bevægelse. Her er tale om æstetiske oplevelser, der sigter mod ekstase, forstået som en (midlertidig) opløsning af fornemmelsen af et begrænset individuelt selv til fordel for oceaniske følelser knyttet til en menneskemasse. Tilstande, der i et mere kritisk perspektiv er blevet kaldt massesuggestion eller massehysteri (Ordbog, 2019). Der er vel ingen grund til at nævne, at disse tilstande kan forstærkes af brug og misbrug af euforiserende stoffer som LSD og ecstasy. 
Interessen for den kollektive oplevelse af grænseoverskridelse er imidlertid ikke kun knyttet til ungdoms- og festkulturer, men optræder også i mere traditionelle klæder. Gospelsang i folkekirkeregi er stadig mere almindeligt, selvom den luthersk-evangeliske kirke ikke er baptistisk. På Vartov, Grundtvigsk Forums bygning i København, er den alsang, der startede under besættelsen, blevet revitaliseret. En fyldt gård samles 4. maj om afsyngelsen af de danske sange (Forum, 2019). Men også på mange lederkurser og konferencer i dag performes ”Magisk Management”, dvs. der opføres ritualer eller ceremonier, der skal skabe en kollektiv følelse af samhørighed gennem taler, sang, dans eller leg (Bøje, 2019 (fortcomming)).

Det mest spektakulære er dog stigningen i udbud og efterspørgsel af meditative aktiviteter. Inden for dansk uddannelse har den spirituelle økonomi meldt sig som en voksende interesse for meditation og mindfulness for såvel børn som voksne. Ofte begrundet som middel til forebyggelse eller afhjælpelse af stress og uro. Mindfulness er som udgangspunkt mental træning inspireret af Buddhismen (Elsass, 2011). En lang række firmaer udbyder certificerede uddannelser på markedsvilkår til priser omkring 15.000, men også det offentlige uddannelsessystem er gået ind på området. I aftalen om satspuljemidler 2018-2021 afsatte regeringen 12,5 millioner til uddannelse af mindfulness-instruktører, der skal arbejde med børn og unge. Uddannelserne kan købes hos de private aktører eller drives af Dansk Center for Mindfulness, der er et forskningscenter ved Århus Universitet (NLP Huset, 2018; Dansk Center for Mindfulness, 2018).v

Tilsvarende vælger forældre i stigende grad religiøse skoler til deres børn. Antallet af elever i friog privatskoler ligger i ligger i dag på omkring 18\%. I hovedstadsområdet dog omkring $25 \%$. Væksten er stærkest for de religiøse skolers vedkommende, dvs. for de katolske og de muslimske i nævnte rækkefølge (Dansk Friskoleforening, 2017)vi Men den spirituelle bevægelse er også tydeligt inden for andre professionsområder i den offentlige sektor. Hospitalspræster og fængselspræster kan f.eks. suppleres af imamer eller rabbinere, hvis det ønskes af de indlagte/indsatte (Rigshospitalet, 2019). Fængselskor er meget populære, tilsyneladende uanset trosretning (Timotheuskirken, 2018). Men også djævleuddrivelse, der inden for en Luthersk tradition må siges at være noget specielt eller ekstremt, finder tilsyneladende sted i et eller andet omfang i den danske folkekirke (Schou, 2019).

Min bekymring er som sagt, at disse spirituelle bevægelser ikke bare er "uskyldige" eller uforpligtende forsøg på at skabe mening, glæde og fællesskab, men at de også kan være 
medvirkende til skabe foragt og eksklusion, kulturelt og socialt. I værste tilfælde til umenneskeliggørelse af de udstødte, som jeg vil vende tilbage til i forbindelse med, hvad jeg vil betegne som ”de danske ø-lejre”, nemlig Sjælsmark og Lindholm. Her følger jeg altså de linjer, som Agamben og Krastev tegner i deres dystopiske politiske scenarier. Men jeg gør det modvilligt, for jeg håber ikke, de er på ret spor. Jeg ønsker hverken en gentagelse af rædslerne før 2. verdenskrig eller tilstandene efter sammenbruddet af Titos Jugoslavien.

\section{Den permanente undtagelsestilstand}

Georgio Agamben (f. 1942) er italiensk jurist, men arbejder i dag tværfagligt med politisk filosofi. Hans aktuelle bidrag til samtidens politiske debat er hans teorier om "State of Exception" eller "Regime of Emergency" (Agamben, 1995, 2014; Humphreys, 2006; Juhl 2016a, 2016b).

"State of Exception” kan på dansk både oversættes til "En undtagelsestilstand” og til "En stat bygget på undtagelser". Ofte bruges begrebet "Sikkerhedsregimet", selvom ”Nødretsregime" måske ville passe bedre”. Helt afgørende er imidlertid, at Agamben taler om en politisk situation, hvor gældende lov med henvisning til en nødsituation eller sikkerhedstrussel mod staten/nationen er sat ud af kraft.

At sætte loven ud af kraft og indføre nødretstilstand har ifølge Agamben altid været suverænens privilegium. Her henviser han til de romerske bystater - suverænen er på én gang garanten for lov og orden og den, der har lov til at ophæve ordenen og indføre undtagelsestilstand. Men historisk har vi set mange andre eksempler på undtagelsestilstande og det dertil knyttede paradigme eller matrice "lejren”. Steder, hvor det menneskelige biomateriale eller det nøgne liv (Arendt 1958), der må udskilles for at konstruere statens eller nationens grænser, isoleres. Lejrene er tilsyneladende harmløse steder, f.eks. et hotel, men

[...] i virkeligheden er det rum, hvor den normale ordning de facto er suspenderet, og om der begås grusomheder eller ikke, afhænger ikke af retten, men kun af den civile og etiske sans hos det politi, der provisorisk handler som en suveræn.

(Agamben, 2005, s. 203) 
Eftersom lejrenes beboere var frataget enhver politisk status og fuldstændigt reduceret til nøgent liv [...] nøjagtigt der hvor politikken bliver biopolitik, og homo sacer virtuelt bliver sammenfaldende med borgeren.

(Agamben 199 [1995]2016 s. 199)

Agamben nævner, hvordan der allerede under "den demokratiske” Weimarrepublik blev etableret lejre, hvor kommunister og jødiske flygtninge fra Øst kunne isoleres. Han nævner det cykelstadion, hvor Vichy regeringen indespærrede de franske jøder, indtil de blev overgivet til tyskere, men også det stadion i Bari, hvor det italienske politi i 1991 isolerede flygtninge fra Albanien, indtil de kunne returneres. Han nævner af gode grunde ikke de lejre i Danmark bl.a. på Lolland-Falster og ved Støvring, hvor tyske flygtninge var anbragt lige efter 2. verdenskrig (DR Radio 2019) (Lylloff, 1999) vii. Men han nævner de såkaldte "sikkerheds-zoner” i de franske lufthavne, hvor rejsende, der anmoder om flygtningestatus, kan tilbageholdes i op til 3 døgn (Les Zones d'atende, 2019). Han kunne i dag også have nævnt øerne Nauru og Manus, hvor de australske myndigheder isolerer asylansøgere uden gyldigt pas eller visa på ubestemt tid, selvom Australien har underskrevet FN’s flygtningekonvention (Haag, 2019).

Som udgangspunkt refererer Agamben til Carl Schmitt (1888-1985), der i sine skrifter argumenterede for, at diktaturet kan være en lige så god en styreform som det parlamentariske demokrati. Carl Schmitt meldte sig efter opfordring fra Martin Heidegger ind i nazistpartiet i 1933, meldte sig ud igen i 36, men forblev aktiv anti-semit (Schmitt, [1932] 1985). Fra Schmitt henter Agamben - ligesom mange andre venstreorienterede politiske analytikere (Laclau \& Mouffe, 1985; Hardt \& Negri, 2001) - opfattelsen af forbindelsen mellem etableringen af statens/nationens biopolitiske krop, etableringen af staten og etableringen af lejrene. Frembringelsen af livet uden rettigheder er identisk med - eller forudsætningen for frembringelsen af statens rettigheder. For at indstifte en politisk orden er det nødvendigt at udstøde det uordentlige. Lejren bliver statens matrice eller paradigme. Den huser det kasserede, der er nødvendigt for konstruktionen af ordenen.

Man bør nu overveje lejrens paradoksale status som undtagelsesrum, der består i et stykke land, der er anbragt uden for den normale retsorden, men som alligevel ikke blot bliver et rum udenfor. Hvad der er udelukket ved den, er i overensstemmelse med termen exceptio (ex-capere) taget ud, inkluderet gennem udelukkelsen af 
samme. Men det, der derved først og fremmest indfanges i ordene, bliver selve undtagelsestilstanden. Eftersom undtagelsestilstanden da også er villet, så indvier den til et nyt politisk paradigme, hvori normen ikke er at skelne fra undtagelsen.

(Agamben, [1995]2016, s.198-1999)

Her åbner Agamben altså for den mulighed, at undtagelsestilstanden ikke er en midlertidig tilstand begrundet i hensynet til statens sikkerhed, men permanent - den normale orden. Og han åbner for, at nøgne liv uden rettigheder ikke kun er lejrenes beboere, men bliver sammenfaldende med borgeren. Den permanente undtagelsestilstand betyder således: Hvad der i nogen tid skulle gælde nogle, gælder altid for alle!

I seneste udtalelser beskriver Agamben nogle radikale forandringer knyttet til spørgsmålet om undtagelsestilstanden (Agamben, 2014). Det er ikke længere relevant at tale om et sikkerhedsregime, der sigter imod at skabe og vedligeholde orden. Tværtimod. Det politiske er ikke længere at skabe orden, men at styre uorden: Hvor det klassiske regime ville styre årsager, vil den (post-)moderne stat kontrollere og styre effekter:

Fordi styring af årsager er besværligt og dyrt, er det mere sikkert og nyttigt at forsøge at styre effekterne”. [...] Ingen har sagt det så tydeligt som en italiensk politi-officer, der efter tumulterne i Genoa i juli 2001 erklærede, at regeringen ikke ønsker at politiet følger ordrer, men at de håndterer uorden.

(Agamben, 2014 (egen oversættelse, 2018)

Denne radikalt forandrede styringsteknologi er en konsekvens af de radikalt forandrede vilkår for statsdannelse. Den moderne nationalstats politiske system er kommet i alvorlig krise, fordi den funktionelle forbindelse mellem en bestemt lokalitet/territorium, en bestemt ordning og en bestemt nativitet/fødsel er de-koblet. Det biologiske materiale, herunder menneskene og de materielle ressourcer, de indtager og udstøder, cirkulerer i princippet grænseløst på kloden. 
Det paradoksale sammenfald i dag af et absolut liberalt paradigme i økonomi med et hidtil ukendt, men lige så absolut paradigme om stat og politikontrol [...] kræver udvidelse og konstant udvikling. Årsager skal kendes, men effekter kan kun blive tjekket og kontrolleret.”

(Agamben, 2014 (egen oversættelse, 2018)

Afgørende for, at kontrollen kan operationaliseres, er de nye biometriske sikkerhedsapparater. I dag kan alle borgere i princippet identificeres ikke kun via fingeraftryk, men også via øjenscanninger og gentest. Ligesom man via "big-data" i princippet kan forudsige sandsynligheden for, at bestemte mennesker befinder sig på bestemte steder og vil foretage sig bestemte forbrydelser (Law, 2014).

Det uudtalte princip, der regerer vores samfund, kan siges at være: "enhver borger er en potentiel terrorist".

(Agamben, 2014 (egen oversættelse, 2018)

Og så er vejen banet for det kulturelle mønster, som Ivan Krastev beskriver i After Europe (2017). Den dominerende diskurs præges stigende grad af polariseringer mellem ”os og dem”. Den europæiske civilisations drøm om frihed og demokrati - Utopia - erstattes af drømmen om Nativia - øen, hvor alle de udstødte og uønskede kan sendes hen.

\section{Paradigmeskiftet}

Hverken Agamben eller Krastev siger noget specifikt om Danmark, når de udtaler sig om de politiske bevægelser i Europa og verden i det hele taget. Men hvis vi fokuserer på det såkaldte "paradigmeskift" i dansk udlændinge- og flygtningepolitik, så er lighederne markante. Vi kan se udpegningen af de uønskede, der skal have særlig behandling, dikotomiseringen mellem dem og os - her danskere og ikke-danskere - samt tendenser til permanent undtagelsestilstand i strid med såvel liberale demokratiske principper som FN’ menneskerettigheder.

Her tre aktuelle nationale eksempler fra børne-og ungeområdet: Obligatoriske laringstilbud til 1årige i udsatte boligområder (Børne- og Socialministeriet, 2018), Regeringen vil gøre op med parallelsamfund (Ghettoudspillet) (Regeringen, 2018), Aftale om initiativer, der modvirker parallelsamfund (Hjemsendelsesydelsen) (Transport og Boligministeriet, 2018; Dansk 
Socialrådgiverforening, 2018) samt Børnehaveklassen (Tvungne Sprogtests før Skolestart, Silkeborg Kompetencecenter, 2019). Og så er der jo også ”de danske ø-lejre”, Sjælsmark-lejren for afviste flygtninge- og asylansøgere, der skal sendes ud af landet, og Lindholm, der i bogstavelig forstand er en ø, hvor kriminelle udviste skal isoleres (Danmarks Radio, 2019).

Når det gælder de "Obligatoriske læringstilbud til 1-årige i udsatte boligområder”, skal jeg atter understrege et forbehold. Jeg argumenterer ikke imod, at små børn skal gå i vuggestue eller andre dagtilbud. Jeg diskuterer, hvor, hvordan og hvorfor det skal foregå.

"Obligatorisk tilbud" er et oxymoron, dvs. et udsagn, hvor to begreber, der logisk strider mod hinanden, kombineres (Den Danske Ordbog). Et tilbud kan man sige nej tak til. Man kan ikke sige nej tak til noget obligatorisk. De obligatoriske læringstilbud er en del af en aftale indgået af den danske regering (Venstre, LA og Konservative) sammen med Socialdemokratiet og DF 2018 som en del af ghetto-planen. Den betyder, at børn fra, hvad der defineres som "udsatte boligområder"viii, og som ikke allerede er optaget i daginstitution eller dagpleje, når barnet fylder 1 år, mindst 25 timer om ugen skal deltage i:

Intensive og målrettede forløb for børn. [ ...] med henblik på at udvikle barnets danske sprog og generelle læringsparathed samt introducere barnet til danske traditioner og højtider (min understregning) i forbindelse med fx jul, påske, grundlovsdag, fødselsdage og fastelavn samt demokratiske normer og værdier. Det handler bl.a. om, at børnene skal opleve, at der er ligevard mellem drenge og piger, at børnene støttes i at lytte til andre og respektere hinandens forskellige synspunkter på tværs af køn og baggrund, og at børnene oplever at have indflydelse på de aktiviteter, der foregår i dagligdagen.

(Børne- og Socialministeriet, 2018, side 2)

I aftalen indgår en aftale om skærpet straf for pligtforsømmelse for ledere i offentlig tjeneste eller hverv. Lederne skal kunne dømmes til op til 1 års fængsel, hvis de f.eks. ikke indberetter forældre til børn, der ikke deltager i tilbuddene. Familierne kan dog få dispensation fra tilbuddet, hvis begge forældres sproglige kompetencer i dansk står mål med 9. klasses afgangsprøve eller Dansk Prøve 3 (Børne- og Socialministeriet, 2018). 
Så her er - som Agamben beskriver - tale om udpegning af en speciel gruppe, der skal have en særlig behandling i særlige rum og om overvågning, kontrol og straf. Selvom det lyder helt harmløst, så er intentionen, at ikke-dansktalende familier, der selv passer deres småbørn, tvinges til at sende børnene til, hvad kunne benævnes som "genopdragelse" i dansk nationalkultur, her overvejende beskrevet som kristen. Hvad der reelt kommer til at ske, vil - som Agamben skriver komme til at afhænge af den etiske sans hos de ansatte. Og her må vi håbe og forvente det bedste, jævnfør den velfærdsstatslige professionsetos, der er så udpræget hos de offentligt ansatte i de nordiske lande (Briggs, 1962; Hjort (ed.), 2018).

Tonen bliver imidlertid skarpere, når vi kommer til det paradigmeskift, der er knyttet til den lov om fjernelse af ghettoer, herunder indførelse af hjemsendelsesydelse, der blev vedtaget i november 2018 af regeringen, DF, Socialdemokratiet og SF. Målet er, at Danmark skal være fri for, hvad der defineres som ghettoer (se slutnote vi) i 2030 (Bollerslev, 2018; Regeringen, 2018).

På børne- og ungeområdet betyder det, at

[...] der må maximalt optages $\underline{30} \%$ børn fra udsatte boligområder (min understregning) i hver daginstitution [...] Privatinstitutioner, som set over et kalenderår har optaget mere end $30 \%$ af børn, som er bosat i et udsat boligområde, skal have tilbagekaldt deres godkendelse.

(Regeringen, 2018, side 25)

Men hvor skal børnene fra disse områder så gå i daginstitution? Hvor skal de bo? Og hvordan skal de forsørges?

Stop for tilflytning af modtagere af integrationsydelse. [...] Vi sætter et ambitiøst mål om, at der ikke skal være ghettoer i Danmark. Alle ghettoer skal væk (min understregning). Det kræver en massiv indsats for at omdanne de udsatte boligområder til almindelige bydele. Blandt andet ved salg af eksisterende bygninger og målrettet nedrivning_(min understregning). Og med nybyggeri af private boliger. [... L Lavere ydelser for ( $\mathrm{min}$ understregning) tilflyttere til ghettoområder” 
Den såkaldte integrationsydelse er en særlig lav ydelse for personer, der har opholdt sig i Danmark i mindre end ni ud af de seneste ti år, Ydelsen svarer til ca. halvdelen af kontanthjælpen. Ydelsen vil i 2020 blive ændret til en selvforsørgelses- og hjemsendelsesydelse og blive beskåret med yderligere 2000 kr. (Pedersen, 2019).

Vi har altså her at gøre med en formuleret politisk strategi, der sigter mod af udskille, udstøde (og udslette?) en bestemt gruppe af mennesker. Krastev's beskrivelse af Nativia rykker tættere på. Med initiativet om Tvungne Sprogtest før Skolestart bliver mønsteret fra den permanente undtagelsestilstand tydeligt. Først gælder det nogle, så alle.

Skoler, hvor mere end $30 \%$ af eleverne kommer fra udsatte boligområder, skal sprogteste deres elever for at sikre, at de har tilstrækkelige sproglige forudsætninger for at kunne fortsætte i 1. klasse.

(Regeringen, 2018, side 26)

Hvis ikke børnene består sprogtesten, kan konsekvensen blive, at de dumper i børnehaveklassen:

Der iværksættes et intensivt sprogstimuleringsforløb for elever med et negativt udfald af sprogprøven. Hvis barnet ikke består en ny sprogprøve efter sommerferien, kan barnet ikke påbegynde 1. klasse. Forslaget omfatter også folkeskoler og de frie grundskoler (min understregning).

(Regeringen, 2018, side 26 ix x)

Men nu er det ikke kun børn fra migrantfamilier, der skal testes. Forslaget rummer krav om beståede tests for alle børn i et område som forudsætning for, at de ikke udelukkes fra at starte i 1. klasse. Sprogstimulering og sommerskolekurser for de 5-6-årige foreslås ganske vist som en forsøgsordning, men anbefalingen er, at denne midlertidige undtagelsestilstand gøres permanent for alle. De samme gælder sanktioneringen, hvis børn og unge generelt ikke møder op til nationale prøver og test generelt.

Børn i folkeskolen skal følge undervisningen. Derfor bortfalder børne- og unge ydelsen i et kvartal, hvis et barn uden gyldig grund har mere end 15\% fravær i et kvartal. Børn i folkeskolen skal møde op til tests og afsluttende prøver. Derfor 
bortfalder børne- og ungeydelsen i førstkommende kvartal, hvis et barn udebliver uden grund.

(Regeringen, 2018, side 27xi)

Udspillet om tvungne tests og prøver er dog ikke gået upåagtet hen. Eksempelvis har en far, Jeppe Søe offentligt erklæret, at han holder sin søn hjemme fra testene, fordi et påbud anfægter de liberale rettigheder i et demokrati, herunder retten til at styre eget privatliv (Bjerrild 23.marts 2017). Protester fra forældre, pædagogiske ledere og den politiske opposition har dog foreløbig ikke fået nogen effekt. Statsminister Lars Løkke Rasmussen har - som nævnt i indledningen formuleret facit sådan her:

”Hvis børnene pjækker og ikke møder op i skolen, så trækkes i børnechecken”

(Larsen, 2018)

\section{Det menneskelige håb}

Hvis vi ser på de eksempler, jeg har beskrevet ovenfor, så tegner der sig et mønster, hvor suverænen i stigende grad udnytter sin magt til at etablere en politisk situation, hvor gældende lov og ret suspenderes. Men det er ikke hele tegningen:

I Danmark har vi med folkeskoleloven 2017 ikke skolepligt, men undervisningspligt (Folketinget, 2017), så Jeppe Søe har ret til at sende sin søn i en tests og prøvefri skole som Freinetskolen eller Rudolf Steiner.

Med grundloven 1953 har vi både sociale og liberale rettigheder, herunder retten til privatliv, ytringsfrihed og minoritetsbeskyttelse (Folketinget, 1953). Så beboerne i de såkaldte ghettoområder har ret til ikke uden grund at blive frataget deres bolig og eksistensgrundlag.

Og med FN’s menneskerettighedserklæring 1948 gælder retten til beskyttelse af liv og velfærd universelt. Det vil sige også flygtninge og asylansøgere, der ikke har dansk statsborgerskab, har ret til beskyttelse. I FN's konvention om Børns Rettigheder understreges særligt, at børn og unge skal beskyttes mod fysisk og psykisk vold, overgreb og udnyttelse (FN, 1989). Med børnekonventionen som udgangspunkt har Røde Kors lavet en ”Rapport om Trivsel hos børn på 
udrejsecenter Sjælsmark” (2019), hvori de påpeger en række stærkt kritisable forhold som sult og psykisk sygdom blandt børnene, og giver anbefalinger til konkrete forbedringer. Institut for Menneskerettigheder (2018) har tilsvarende påpeget, hvad de benævner som ”Menneskeretslige udfordringer ved udrejsecenter Lindholm”, herunder planen, om at de afviste ikke må forlade øen.

Hvis man ser på det beskrevne mønster i sin helhed - småt og stort - så tegner der sig, hvad Ernesto Laclau \& Chantal Mouffe kalder en "ækvivalenskæde" (1995). En diskursiv konstruktion af begreber, der ikke er logisk forbundne, men relaterer sig til hinanden gennem identifikation og dikotomisering. I dette tilfælde er nøgleordet eller nodalpunktet begrebet dansk, der identificeres med kristen, der bliver lig med ikke vestlig lig muslim lig potentiel terrorist lig udansk. En associationskæde, der ikke kun installerer en polarisering mellem ”os og dem”, men også legitimerer overvågning og udskillelse af”de andre”. Holdninger og handlinger, der ikke harmonerer særligt godt med næstekærlighedsbudskabet i en kultur, der vil kalde sig kristen.

Men tilbage til Foucault. Den politiske spiritualitet - eller det vi her kalder populistisk spiritualitet - opsamler som udgangspunkt en social og kulturel utilpashed eller utilpassethed og kobler den med troen på en stærk leder, ønsket om et tæt fællesskab og håbet om en bedre verden. Den drøm er ikke nødvendigvis kun destruktiv, men kan rumme utopier og potentialer. Ernst Bloch (1954) formulerer det således:

Alles liv er gennemtrængt af dagdrømme: en del af dette er kun tom, endda enerverende eskapisme, endda bytte for svindlere, men en anden del er udfordrende, er ikke tilfreds med at acceptere det dårlige, der findes, accepterer ikke afkald. Denne anden del har håb som sin kerne, og det kan læres.

(Bloch, 1954, side 1) 


\section{Referencer}

Agamben, G. ([1995] 2016). Homo Sacer - Den suverane magt og det nøgne liv. Århus: Klim.

Agamben, G. (05. 02 2014). For a Theory of Destituent Power. Critical Legal Thinking 5-2. Hentet fra http://criticallegalthinking.com/ hentet .

Arendt, H. ([1958] 2005). Menneskets Vilkår. København: Gyldendal.

Beskæftigelsesministeriet. (2017). Kontanthjalp satser. Hentet fra https://bm.dk/ydelsersatser/satser-for-2018/kontanthjaelp/.

Birk, C. (2017). "Den alternative tro har bidt sig fast hos danskerne”. Kristelig Dagblad 20-072017. Kristeligt Dagblad2007-2017, 1. Hentet fra Birk, C. (2017):”Den alternative tro har bidt sig fast hos danskerne”. Kristelig Dagblad 20-07-2017.

Bjerril, S. (20. 04 2017). I dag er der sygetests: Far holder igen søn hjemme. Hentet fra https://www.folkeskolen.dk/606594/i-dag-er-der-sygetest-far-holder-igen-soen-hjemme-.

Bloch, E. (([1954] 1995). The Principle of Hope. Boston: MIT.

Boligministeriet, T. o. (09. 05 2018). Aftale om initiativer på boligområdet, der modvirker parallelsamfund. Hentet fra https://www.trm.dk/da/politiske aftaler/2018/.

Bollerslev, A. (2018). Regeringens Ghettoudspil. DR.dk.

Boltanski, L. \&. Thévenot, L (1999). The Sociology of Critical Captital. European Journal of Social Theory Vol 2 no 3, s. 359-377. https://doi.org/10.1177/136843199002003010

Briggs, A. (1961). The Wellfare State in Historical Perspektive. European Journal of Sociology Vol 2, No 2, s. 22 1-258. https://doi.org/10.1017/S0003975600000412

Bøje, J. D. (2019 fortcomming). Skoleledelse mellem profan hverdagspraksis, magisk management og religiøst lederskab. En skoleleder skal også huske at bære skraldet ud. Tidsskrift for Professionsstudier.

Børne- og Socialministeriet. (28. 09 2018). Aftale om obligatorisk laringstilbud til 1 årige $i$ udsatte bolig. Hentet fra https://socialministeriet.dk/nyheder/nyhedsarkiv/2018/maj/aftale-omobligatorisk-laeringstilbud-til-1-aarige-i-udsatte-boligomraader-og-skaerpet-straf-til-ledere-forpligtforsoemmelser/.

Chiapello, B. (2007). The New Spirit of Capitalism. London/New York: Verso.

Clough, P. (2007). The Affective Turn - Theorizing the Social. Durham: Duke University Press. https://doi.org/10.1215/9780822389606

Danske Privatskoler. (10.12 2018). Danske Privatskoler-grundskoler og gymnasier. Hentet fra privateskoler.dk.

Den danske ordbog. (06. 04 2019). Den danske Ordbog. Hentet fra Ordnet.dk. 
DR.dk. (01. 03 2018). Fravar i folkeskolen skal udlose straf til hele familien. Hentet fra http://www.dr.dk/nyheder/politik/fravaer-i-folkeskolen-skal-udloese-oekonomisk-straf-til-helefamilien.

Dr.dk. (01. 03 2018). Hvis Børnene pjakker. Hentet fra

https://www.dr.dk/nyheder/politik/fravaer-i-folkeskolen-skal-udloese-oekonomisk-straf-til-helefamilien.

Elkjær, J. B. (31. 10 2017). Danskerne dropper religion - antallet af ikke-troende er i stark vakst. Hentet fra nyheder.tv2.dk.

FN. (10. 12 1948). Menneskerettigheder. Hentet fra

http://www.justitsministeriet.dk/arbejdsomraader/international/menneskerettigheder/fn-ogmenneskerettigheder.

FN. (20. 11 1989). Konvention om Barnets Rettigheder. Hentet fra

https://www.retsinformation.dk/forms/r0710.aspx?id=60837.

Folkeskolen. (20. 04 2017). I dag er der sygetest -far holder igen søn hjemme. Hentet fra

https://www.folkeskolen.dk/606594/i-dag-er-der-sygetest-far-holder-igen-soen-hjemme-.

Folketinget. (1953). Grundloven med forklaringer. Hentet fra

https://www.ft.dk/da/folkestyret/grundloven-og-folkestyret/grundloven-med-forklaringer.

Folketinget. (12.12 20). Lov om folkeskolen lov. nr. 1445. Hentet fra

https://www.retsinformation.dk/Forms/rO7 10.aspx?id=196651.

Folketinget. (12.12 2017). Folkeskoleloven lov 1445. Hentet fra

https://www.retsinformation.dk/Forms/ro7 10.aspx?id=196651.

Folketinget. (30. 05 2017). Lov om andring af dagtilbudsloven. Hentet fra https://www.retsinformation.dk/Forms/Ro7 10.aspx?id=188875.

Forum, G. (31.03 2019). 4. maj i Vartovs Grønnegard-alsang $i$ anledning af befrielsen. Hentet fra https://grundtvig.dk/event/4-maj-i-vartovs-groennegaard-moderne-alsang-i-anledning-afbefrielsen/.

Friskoleforening, D. (19. 062017 b). Muslimske Frie grundskoler - registerbaseret sammenligning af elevernes sociale baggrund på muslimske friskoler og resten af grundskolesektoren. Hentet fra https://www.friskoler.dk/fileadmin/filer/Dansk_Friskoleforening/Presse_og_politik/Analyser_ og_unders\%C3\%B8gelser/Notat_muslimske_frie_grundskoler.pdf hentet 19-06-2016.

Friskolerne. (29. 03 2018). Friskolerne. Hentet fra https://www.timotheuskirken.dk/begivenhed/calendar/2019/03/30/event/tx_cal_phpicalendar /aa-d4ffe $54 \mathrm{c} 62 /$.

Hjort, K. (2001). Moderniseringen af den offentlige sektor. København: Samfundslitteratur.

Hjort, K. (2005). Professionaliseringen i den offentllige sektor. København: Samfundslitteratur. 
Hjort, K. (2008). Demokratiseringen af den offentlige sektor. København: Samfundslitteratur.

Hjort, K. (2008). Demokratiseringen af den offentlige sektor. København: Samfundslitteratur.

Hjort, K. (2012). Det affektive Arbejde. København : Samfundslitteratur.

Hjort, K. (7. 112013 ). Farvelfærdsstaten. Kappe til doktordisputats. Odense: Syddansk Universitet, Det Humanistiske Fakultet.

Hjort, K. (2013). Farvelferdsstat - kappe til doktordisputats. Odense: Odense Boghandel.

Hjort, K. (2018). Profesjonsetikk. Oslo: Norsk Gyldendal.

Houtman, D. \& Aupers, S (2007). The Spiritual Turn and the Decline of Tradition: The Spread of Post-Christian Spirituality im 14 Western Conuntries, 1981-2000. Journal for Scientific Studie of Religion, s. 305-320.

Humphreys, S. (2006). Legalizing Lawlessness - On Giorgio Agamben's State of Exceptiom. The European Journal of International Law, Vol.17, nr 3, s. 677-687.

https://doi.org/10.1093/ejil/chlo20

Haag, J. (04. 01 2019). En tredjedel har forsøgt selvmord på flygtningeø. Hentet fra https://jyllandsposten.dk/international/ECE 1 1044599/en-tredjedel-har-forsoegt-selvmord-paa-australskflygtningeoe/.

Institut for menneskerettigheder. (6. 12 2018). Menneskeretslige udforfordringer ved udrejsecenter på Lindholm. Hentet fra https://www.rodekors.dk/sjaelsmark.

Juhl, C. (2016). Efterskrift. I G. Agamben, Homo Sacer (s. 229-257). Århus : Klim.

Juhl, C. (2016). Indledning. I G. Agamben, Homo Sacer (s. 13-27). Århus: Klim.

Kompetencecenter Silkeborg. (04. 05 2019). O-6 årige Sprogvurdering. Hentet fra https://kompetencecenter.silkeborg.dk/o-til-6-aarige/Sprogvurdering.

Korsgaard, O. (2014). Kampen om Folket - Et dannelsesperspektiv på dansk historie gennem 500 år”. Kbh: Gyldendal . København: Gyldendal.

Krastev, I. (2017). After Europe. Philadelphia: University of Pennsylvania Press. https://doi.org/10.9783/9780812294262

Køningsfeldt, A. (08. 11 2016). Flertal af danskerne: Religion er ikke meget vigtigt $i$ mit liv. Hentet fra dr.dk.

Laclau, E. \&. ([1985] 200)). Hegemony and Socialist Strategi. Londom/NY: Verso.

Laclau, E. (1994). Why do empty signifiers matter in Politics. I W. ed, The Lesser Evil and The Greater Good (s. 167-178). London: River Gram Press.

Larsen, J. (6. 11 2018). Hentet fra https://www.dk/nyheder/politik/. 
Larsen, J. B. (01.03 2018). fravaer-i-folkeskolen-skal-udloese-oekonomisk-straf-til-hele-familien. Hentet fra https://www.dr.dk/nyheder/politik/fravaer-i-folkeskolen-skal-udloese-oekonomisk-straf-tilhele-familien.

Law, J. (2004). After methods mess in social science research. . NY: Routledge.

Lylloff, K. (1999:1). Kan lægeløftet gradbøjes - Dødsfald blandt og lægehjælp tilde tyske flygtningen 1945. Hitorisk Tidsskrift, s. 33-67. Hentet fra http://www.historisktidsskrift.dk/summary/99_33.html.

Marx, K. (1857). Grundridse der Kritik der Politischen Ökonomie Retrieved from wwrw.marxists.org/archive/marx/work/1857/gundrisse. Hentet fra Retrieved from www.marxists.org/archive/marx/work/1857/gundrisse.

Min-mave.dk. (14.12 2018). Hvor meget $i$ bornepenge. Hentet fra https://www.minmave.dk/artikel/familie/bornepenge.html.

Mouillier-Boutang, Y. ([2004] 2012). Cognitive Capitalism. Cambridge: Polity Press.

Negri, H. (2001). Empire. Harward: Harward University Press.

Ordbog, D. d. (31. 03 2019). Massehysteri. Hentet fra https://www.rigshospitalet.dk/vejledningog-rettigheder/personlig-vejledning/Sider/imam.aspx.

Pedersen, H. (u.d.). o2o bliver andret til en selvforsørgelses- og hjemsendelsesydelse, bliver beskåret med op til $2000 \mathrm{kr}$. DDen såkaldte integrationsyde er at presse udlandinge, som det aldrig er set for $i$ Danmark,

Pedersen, H. (17. 02 2019). Integrationsydelse er at presse folk på nye måder. Hentet fra https://www.bt.dk/samfund/ekspert-om-ny-integrationsydelse-det-er-at-presse-folk-paa-enmaade-vi-har-aldrig.

Pedersen, H. (20. 02 2019). Regeringens integrationsydelse er at presse folk på en ny måde, vi aldig har set for. Hentet fra https://www.bt.dk/samfund/ekspert-om-ny-integrationsydelse-det-er-atpresse-folk-paa-en-maade-vi-har-aldrig.

Radio, D. (21. 02 2019). Paradigmeskiftet vedtaget i folketinget. Hentet fra https://www.dr.dk/nyheder/politik/paradigmeskiftet-vedtaget-i-folketinget-her-erstramningerne-paa-udlaendingeomraadet.

Radio, D. (31. 03 2019). Tyske flygtningen i Danmark. Hentet fra https://www.google.dk/search? source=hp\&ei=Td2gXIWuPI7isAfWvpugAQ\&q=tyske+flygtnin ge $+\mathrm{i}+$ danmark\&oq=tyske+flygt\&gs_l=psyab.1.1.35i39jol6joi203jol2.2648.7161..9507...0.0..0.313.1561.2j9joj1..........1..gwswiz........oi 131 joi67.vKaRx6kHsb4.

Raffnsøe, S. (19. 06 2018). En Åbning mod en Bedre Verden. Information. København: Dagbladet Information.

Ranciere, J. (([2005]2013). Hadet til Demokratiet. Horsens: Møller. 
Regeringen. (2018). Et Danmark uden parallelsamfund 2030. Hentet fra https://www.regeringen.dk/media/4937/publikation_ét-danmark-uden-parallelsamfund.pdf. Regeringen. (2018). https://www.regeringen.dk/publikationer-og-aftaletekster/\%C3\%A9tdanmark-uden-parallelsamfund/. Et Danmark uden parallelsamfund.

Regeringen. (21.04 2019). Regeringen vil gøre op med parallelsamfund. Hentet fra https://www.regeringen.dk/nyheder/ghettoudspil/.

Regeringen. (u.d.). Regeringen vil gøre op med ghettoer. Hentet fra https://www.regeringen.dk/nyheder/ghettoudspil/.

Rigshospitalet. (31.03 2019). Iman Rigshopspitalet. Hentet fra https://www.rigshospitalet.dk/vejledning-og-rettigheder/personligvejledning/Sider/imam.aspx.

Ritzau. (14. 10 2018). Børnechecken beskeres. Hentet fra https://www.fyens.dk/indland/Boernechecken-beskaeres-Skolefravaer-ventes-at-koste-4100foraeldre-penge/artikel/3292772.

Rosa, H. (u.d.). Social Acceleration - A New Theory of Modernity. New York: Columbia University Press.

Røde Kors. (05. 03 2019). Rapport om trivsel hos børn på udrejsecenter Sjalsmark. Hentet fra https://www.rodekors.dk/sjaelsmark.

Røde Kors. (05. 03 2019). Trivsel hos børn på udrejsecenter Sjalsmark. Hentet fra https://www.rodekors.dk/sjaelsmark.

Schanz, H. J. (1973). Til rekonstruktion af den politiske økonomis omfangslogiske status. . Århus: Modtryk.

Schmitt, C. ([1932] 1985). Det politiskes begreb. København: Hans Reitzels Forlag.

Schou, K. (09. 01 2019). Folkekirkens prester kan også uddrive damoner. Hentet fra https://www.kristeligt-dagblad.dk/kirke-tro/folkekirkens-praester-kan-ogsaa-uddrive-daemoner. Socialministeriet. (2). Hentet fra https://socialministeriet.dk/arbejdsomraader/dagtilbud/aftalenom-parallelsamfund/.

Socialministeriet, B. o. (05 2018). Aftale om obligatorisk laringstilbud til 1-årige i udsatte boligområder og skarpet straffor ledere for pligtforsømmelse. Hentet fra https://socialministeriet.dk/nyheder/nyhedsarkiv/2018/mah.

Socialrådgiverforening, D. (20. 12 2018). Sådan rammer udlandingestramningerne. Hentet fra https://www.socialraadgiverne.dk/saadan-rammer-udlaendingestramningerne/.

Sundhedsstyrelsen. (20.05 2018). Sundhedsstyrelsen. Hentet fra https://www.sst.dk/dattps\%3A\%2F\%2Fwww.sst.dk\%2Fda\%2Fsundhed-og-livsstil\%2Fboern-og- 
unge $\% 2$ F spaedboern-og-

smaaboern\&cludorefpt=Sp\%C3\%A6db\%C3\%B8rn\%20og\%20sm\%C3\%A5b\%C3\%B8rn.

Tagmose, A. (05. 12 2016). Hver fjerde danske tror på engle. Epinion for DR og Politiken. Hentet fra http://www.dr.dk.

Thomsen, H. J. (1975). Ansats til en begribelse af dobbeltlogikken hos Marx. Arhus. ^Åthus: Århus Universitet, Institut for Idehistorie.

Timotheuskirken. (29. 03 2018). Timotheuskirken. Hentet fra

https://www.timotheuskirken.dk/begivenhed/calendar/2019/03/30/event/tx_cal_phpicalendar /aa-d4ffe54c62/.

Trafik-, Bolig og Byggestyrelsen. (20. 09 2018). På ghettol-listen står. Hentet fra På ghetto-listen står i 201830 boligområder fortrinsvis omkring de store byer i Danmark (Trafik-, Bolig- og Byggestyrelsen 2018). Kriterierne for at blive placeret på ghetto-listen er at området sammenlignet med landsgennemsnittet har: En høj andel af.

Transport-, Bolig-og Bygningsstyrelsen. (09. 05 2018). Aftale om initiativer på boligområdet, der modvirker parallelsamfunf. Hentet fra https://www.trm.dk/da/politiske-aftaler/2018/aftale-ominitiativer-paa-boligomraadet-der-modvirker-parallelsamfund.

TV2. (30. 11 2018). Regeringen og df er $i$ mål med en finanslov. Hentet fra http://nyheder.tv2.dk/politik/2018-1 1-30-regeringen-og-df-er-i-maal-med-en-finanslov-her-erhovedpunkterne.

Undervisningsministerier. (6. 11 2018). Børnehaveklassen. Hentet fra https://www.uvm.dk/folkeskolen/fag-timetal-og-overgange/skolestart-ogboernehaveklassen/boernehaveklassen.

Undervisningsministeriet. (25. 022017 a). https://vive.dk/2017/09/andelen-elever-privatskolevokser/. Hentet fra andel-elever-privatskoler.

Wikipedia. (31.03 2019). Les Zones d'atende. Hentet fra https://fr.wikipedia.org/wiki/Zone_d\%27attente_pour_personnes_en_instance.

www.dr.dk. (01.03 2018). Fravar i folkeskolen skal udløse økonomisk straf til hele familien. Hentet fra https://www.dk/nyheder/politik/.

\footnotetext{
${ }^{\mathrm{i}}$ Houtman \& Aupers' konklusioner bygger på et omfattende empirisk materiale, der kombinerer kvalitative interviews med tre runder spørgeskemaer, 1981, 1990 og 2000. Respondenterne er blevet bedt om at sige ja eller nej til fem spørgsmål: Tror du på eksistensen af en spirituel kraft eller livskraft? Tror du på et liv efter døden, men mener ikke, at kirkerne giver adækvate svar på folks spirituelle behov? Tror du på reinkarnation, men ikke på Gud? Tilhører du ikke en religiøs organisering, men betragter dig heller ikke som en overbevist ateist? Betragter du ikke dig selv som en overbevist ateist, men har ikke megen tiltro til kirkerne?
} 
ii Mindre omfattende danske undersøgelser viser samme type paradokser som H\&A’s. På den ene side spiller troen en stadig mindre rolle for befolkningen. Eksempelvis erklærer ca. halvdelen af danskerne i 2016 sig enige i udsagnet "Religion er ikke meget vigtigt i mit liv". I folkekirken er andelen af ikke-troende steget fra 31 til 48\% i perioden 2011-2017. På den anden side tilkendegiver stadig flere, at de forholder sig til forskellige former for semireligiøs eller multireligiøs tænkning med inspiration fra mange forskellige religioner, fra mange forskellige steder på kloden. I 2016 siger $25 \%$ ja til, at de tror på engle. $52 \%$ mener, at "der er mere mellem himmel og jord", og at der findes sandheder i mange religioner (Køningsfeldt 2016, Elkjær 2017, Tagmose 2016, Birk 2017).

iii Central referencer:”. Luc Boltanski \& Eve Chiapello [1999] :"The Sociology of Cognitive Capitalism” [1999] "The New Spirit of Capitalism" [2007]. Yann Moulier-Boutang [2007]: "Cognitive Capitalism” [2004]

iv Central reference: Patricia Tineto Clough (ed): "The Affective Turn - Theorizing the Social".

v Når meditation og mindfulness er så populært i arbejdet med børn og unge, kunne man nære den mistanke, at undernormering i daginstitutioner og inklusion af bl.a. ADHD-diagnosticerede elever i normalklasserne, kunne skabe en uro, som meditationsaktiviteter kan være med til at dæmpe. Men også blandt voksne kan meditation optræde som et redskab til at håndtere den stress og udmattelse, som den stadig hastigere samfundsmæssige acceleration medfører (Rosa 2013).

vi Selvorganiserede skoler har som bekendt været en liberal rettighed i Danmark siden 1849, men den politiske bekymring i dag er, at fravalget af folkeskolen kan medvirke til en forstærket social og kulturel selektion. Medvirke til en øget fragmentering og segrering af samfundet med deraf følgende udfordringer til den demokratiske sammenhængskraft (Undervisningsministeriet 2017 , Korsgaard 2014, Krastev 2017, Friskolerne 2019).

vii Lejrene for tyske flygtninge efter krigen var genstand for et stor strid efter befrielsen. Englænderne krævede, at de tyske (båd-) flygtninge (flertallet kvinder, børn og syge) fra det, der senere blev Øst-zonen, blev i Danmark til et politisk stridspunkt. Den almindelige danske lægeforening stillede som krav for at hjælpe flygtningene i lejrene, at danske soldater, der var interneret $\mathrm{i}$ Tyskland, hjemsendtes. Denne handel blev ikke til noget, så lægeforeningen udstedte et påbud til de danske læger om, at de ikke måtte gå ind i lejrene og praktisere. Det var der nogle læger, der gjorde alligevel. (Lylloff (1999): ”Kan lægeløftet gradbøjes Dødsfald blandt og lægehjælp til de tyske flygtninge 1945”.

viii På ghetto-listen står i 201830 boligområder fortrinsvis omkring de store byer i Danmark (Trafik-, Bolig- og Byggestyrelsen 2018). Kriterierne for at blive placeret på ghetto-listen er at området sammenlignet med

landsgennemsnittet har: En høj andel af indvandrere eller efterkommere af indvandrere fra ikke-vestlige lande. (Flere end 50\%). En høj andel af beboere uden arbejde (Andelen af 18-64-årige, der ikke har tilknytning til arbejdsmarkedet overstiger $40 \%$ opgjort som gennemsnit over de sidste 2 år). En høj andel, der kun har taget en afgangsprøve i folkeskolen. (Mere end 60 \% af de 30-59-årige har ingen uddannelse ud over grundskolen. Kun danske eksaminer medregnes, ikke merit for udenlandske eksaminer). En høj andel af personer med lav indkomst. (Den gennemsnitlige bruttoindkomst er mindre end $55 \%$ af den gennemsnitlige). En høj andel af beboere, der er dømt for kriminalitet. (Andelen af beboere på 18 år og derover dømt for overtrædelse af straffeloven, våbenloven eller lov om euforiserende stoffer udgør mindst 3 gange landsgennemsnittet opgjort som gennemsnit de seneste 2 år) (Transportstyrelsen m.fl. 2018).

ix De frie skoler i Danmark består af privatskoler, der alle afholder afgangseksaminer og nationale prøver, samt friskoler, hvoraf en stigende andel er prøve og testfri. (Danske Privatskoler, 2018).

x Alle børn i 3-årsalderen skal i forvejen sprogvurderes, hvis personalet i dagtilbuddene skønner, at der er behov for det. Kommunerne har fra 1. juli 2017 fået lov til at fremrykke sprogvurdering og sprogstimulation til 2. årsalderen med denne begrundelse: ”Forskning viser, at en tidlig indsats (0-3 år) i forhold til at styrke børns kognitive, sociale og emotionelle kompetencer er den mest omkostningseffektive indsats (Regeringen 2018 side 24).

xi Børnechecken er i 2018 før skat ca. 18.000 kr. om året for 0-2-årige og ca. 14.000 for 3-årige. Min-mave 2018. 